\begin{tabular}{lcc}
\hline Ročník LIII Cí́slo 1, 2005 & 5 &
\end{tabular}

\title{
NONTARGET LEPIDOPTERA SPECIES FOUND IN THE PHEROMONE TRAPS FOR SELECTED TORTRICID SPECIES IN 2002 AND 2003 YEARS
}

\author{
E. Hrudová
}

\author{
Received: August 9, 2004
}

\begin{abstract}
HRUDOVÁ, E.: Nontarget lepidoptera species found in the pheromone traps for selected Tortricid species in 2002 and 2003 years. Acta univ. agric. et silvic. Mendel. Brun., 2005, LIII, No. 1, pp. 35-44

Pheromone traps were used to monitor the following tortricid moths, i.e. Adoxophyes orana, Archips podanus, A. rosanus, Hedya nubiferana, Pandemis heparana, Spilonota ocellana, Cydia pomonella, Cydia funebrana and Cydia molesta in the localities Brno-Turany (Brno-město), Nebovidy (Brnovenkov) and Prakšice (Uherské Hradiště). Other Lepidoptera non-target species were present in these target-species pheromone traps, i.e. Adoxophyes orana, Agrotis segetum, Amphipoea oculaea, Archips rosanus, Celypha striana, Cydia coronillana, Enarmonia formosana, Epiblema scutulanum, Epinotia huebneriana, Eucosma fervidana, Euxoa tritici, Hedya pruniana, H. nubiferana, Lymantria dispar, Noctua pronuba, Notocelia rosaecolana, N. roborana, Pammene albuginana, P. suspectana, Pandemis cerasana, Pyrausta rectefascialis, P. aurata, Spilonota ocellana, Yponomeuta malinellus and Zygaena purpuralis.
\end{abstract}

fruit tortricid moths, pheromone traps, South Moravia, intensive orchard, extensive orchard, non-target moth species, Noctuidae, Pyralidae, Yponomeutidae

In practice the use of pheromone traps for tortricid moths is often complicated because also non-target species are captured. Especially the trapping of habitually similar species is important because their presence could distort the data used for treatment prediction. It is therefore important to know the spectrum of the non-target species and why they are attracted. Tortricid moths, i.e. summer fruit tortrix Adoxophyes orana (Fischer, 1834), fruit tree tortrix Archips podanus (Scopoli, 1763), rose tortrix moth A. rosanus (Linnaeus, 1758), green budworm Hedya nubiferana (Haworth, 1811), eye-spotted bud moth Spilonota ocellana (Denis \& Schiffermüller, 1775), codling moth Cydia pomonella (Linnaeus, 1758), plum fruit moth Cydia funebrana (Treitschke, 1835) and oriental fruit moth Cydia molesta (Busck, 1916) are important pests of fruit trees of the Rosaceae family. HRDÝ et al. (1979) tested sex pheromones for C. funebrana, C. molesta, and Anarsia lineatella Zeller, 1839 and they found that also non-target species were captured in the traps (Tab. I). In Japan, while monitoring C. pomonella, HIRAMATSU et al. (1992) discovered that the pheromone of this species attracted males of the genera Aterpia, Hedya, Eucosma, Grapholita and Pammene. The species of the Archipini tribe have a common component of pheromone (Z)-11-tetradecenyl acetate (OKU, 1993). 
I: Nontarget moths species refered by many authors

\begin{tabular}{|c|c|c|c|}
\hline $\begin{array}{l}\text { Target species } \\
\text { Cílový druh }\end{array}$ & $\begin{array}{c}\text { The target species } \\
\text { pheromone } \\
\text { Feromon cílového druhu }\end{array}$ & $\begin{array}{l}\text { Nontarget species } \\
\text { Necílový druh }\end{array}$ & $\begin{array}{l}\text { Authors } \\
\text { Autor }\end{array}$ \\
\hline \multirow[t]{13}{*}{ Cydia funebrana } & \multirow[t]{13}{*}{$\begin{array}{l}\text { (Z)8-dodecenyl acetate } \\
\text { (E)8-dodecenyl acetate }\end{array}$} & $\begin{array}{l}\text { Pammene aurana (Fabricius, } \\
1775 \text { ) }\end{array}$ & $\begin{array}{l}\text { Hrdý et al. 1979; Hrdý et } \\
\text { al. } 1997\end{array}$ \\
\hline & & $\begin{array}{l}\text { P. suspectana (Lng. \& Zeller, } \\
\text { 1849) }\end{array}$ & $\begin{array}{l}\text { Hrdý et al. 1979; Hrdý et } \\
\text { al. } 1997\end{array}$ \\
\hline & & P. fasciana (Linnaeus, 1761) & Hrdý et al., 1993 \\
\hline & & P. amygdalana (Duponchel, 1842) & Hrdý et al. 1997 \\
\hline & & P. aurita (Razowski, 1991) & Hrdý et al. 1997 \\
\hline & & P. spiniana (Duponchel, 1843) & $\begin{array}{l}\text { Mayer \& McLaughlin in } \\
\text { Hrdý et al. } 1997\end{array}$ \\
\hline & & $\begin{array}{l}\text { Enarmonia formosana (Scopoli, } \\
\text { 1763) }\end{array}$ & $\begin{array}{l}\text { Hrdý et al. 1979; Hrdý et } \\
\text { al. } 1993\end{array}$ \\
\hline & & $\begin{array}{l}\text { Epiblema foenellum (Linnaeus, } \\
1758 \text { ) }\end{array}$ & Hrdý et al. 1979 \\
\hline & & $\begin{array}{l}\text { E. scutulanum (Den. \& Schiff., } \\
\text { 1775) }\end{array}$ & $\begin{array}{l}\text { Hrdý et al. 1979; Hrdý et } \\
\text { al. } 1993\end{array}$ \\
\hline & & $\begin{array}{l}\text { Celypha striana (Den. \& Schiff., } \\
1775 \text { ) }\end{array}$ & Hrdý et al. 1993 \\
\hline & & $\begin{array}{l}\text { Cnephasia genitalana (Pierce \& } \\
\text { Metcalfe,1922) }\end{array}$ & Hrdý et al. 1993 \\
\hline & & $\begin{array}{l}\text { C. stephensiana } \\
\text { (Doubleday,1849) }\end{array}$ & Hrdý et al. 1993 \\
\hline & & $\begin{array}{l}\text { Cydia tenebrosana (Duponchel, } \\
1834 \text { ) }\end{array}$ & Hrdý et al. 1993 \\
\hline \multirow[t]{9}{*}{ C. molesta } & \multirow{9}{*}{$\begin{array}{l}\text { (Z)8-dodecenyl acetate } \\
\text { E(8)- dodecenyl acetate } \\
\text { (Z)-8- dodecen-1-ol }\end{array}$} & Pammene fasciana & Hrdý et al. 1993 \\
\hline & & Enarmonia formosana & Hrdý et al. 1993 \\
\hline & & Epiblema scutulanum & Hrdý et al. 1979 \\
\hline & & Celypha striana & Hrdý et al. 1993 \\
\hline & & Cnephasia stephensiana & Hrdý et al. 1979 \\
\hline & & C. genitalana & Hrdý et al. 1993 \\
\hline & & Cydia janthiana & Hrdý et al. 1997 \\
\hline & & C. tenebrosana & Hrdý et al. 1993 \\
\hline & & Hedya pruniana & Hrdý et al. 1989 \\
\hline C.pomonella & & $\begin{array}{l}\text { Aterpia, Hedya, Eucosma, } \\
\text { Grapholita, Pammene }\end{array}$ & Hiramatsu et al., 1992 \\
\hline $\begin{array}{l}\text { Anarsia lineatella } \\
\text { (Zeller, 1839) }\end{array}$ & $\begin{array}{l}\text { (E)-5-decene-1-yl acetate; } \\
\text { (E)-5-decene-1-ol }\end{array}$ & $\begin{array}{l}\text { Diachrysia chrysitis (Linnaeus, } \\
1758) \\
\text { Mesapamea secalis (Linnaeus, } \\
1758) \\
\text { Lacanobia suasa (Den. \& Schiff., } \\
1775) \\
\text { Apamaea sordens (Hufnagel, } \\
1766)\end{array}$ & Hrdý et al. 1993 \\
\hline $\begin{array}{l}\text { Pandemis } \\
\text { heparana }\end{array}$ & & Noctua fimbriata (Schreber, 1759) & Hrdý et al. 1993 \\
\hline $\begin{array}{l}\text { Hedya nubiferana } \\
\text { (Haworth, 1811) }\end{array}$ & $\begin{array}{l}\text { (E,E)-8,10-dodecadien-1- } \\
\text { ol-acetate; (Z)-8-dodecenyl } \\
\text { acetate ; dodecenyl acetate }\end{array}$ & $\begin{array}{l}\text { Cydia janthiana (Duponchel, } \\
1835 \text { ) }\end{array}$ & Hrdý et al. 1997 \\
\hline
\end{tabular}




\section{MATERIAL AND METHODS}

Delta-type pheromone traps were used to monitor the following important tortricid moths species Adoxophyes orana, Archips podanus, A. rosanus, Hedya nubiferana, Spilonota ocellana, Cydia pomonella, Cydia funebrana and Cydia molesta; in 2002 in the localities Brno-Tuřany (Brno-město district) and Prakšice (Uherské Hradiště district), and in 2003 in the Nebovidy locality. The traps were placed in the tree crowns at a height of $150 \mathrm{~cm}$ ca $20 \mathrm{~m}$ apart; in Turany (apple and peach trees) they were placed approximately in the middle of the tree crown, in Prakšice (apple and plum trees) and Nebovidy (apple, pear, plum and apricot trees) in the middle of the crown 1-2 $\mathrm{m}$ from the stem. In 2002 the commercial pheromone traps were obtained from ZD Farm Chelčice under the mark Biolatrap. The pheromone dispensers contained the following substances: for $A$. orana (Z)-11-tetradecenyl acetate, (Z)-9-tetradecenyl acetate, A. podanus (Z)-11-tetradecenyl acetate and (E)-11-tetradecenyl acetate, A. rosanus (Z)-11-tetradecenyl-acetate, (Z)-11-tetradecene-1-ol, Hedya nubiferana (E,E)-8,10-dodekadiene-1-yl-acetate, (Z)-8-dodecene-1-yl-acetate, Spilonota ocellana (Z)-8-tetradecene-1-yl-acetate, Pandemis heparana (Z)-11-tetradecene-1-yl-acetate, Cydia pomonella $(8,10)-8,10$-dodekadiene-1-ol, Cydia funebrana (Z)8-dodecene-1-yl acetate, (E)-8-dodecene-1-yl acetate, (Z)-8-tetradecene-1-yl acetate and tetradecyl acetate and for Cydia molesta (Z)-8- dodecene-1-yl acetate, (E)-8-dodecene-1-yl acetate and (Z)-8-dodecene-1-ol (www.nysaes.cornell.edu) ${ }^{1}$.

In 2003 the same species of tortricid moths were discovered in the localities Tuřany, Prakšice and Nebovidy. The pheromones for Adoxophyes orana, Archips podanus, A. rosanus and Hedya nubiferana were obtained from ZD Farm Chelčice. The pheromones for Cydia pomonella - (E,E)-8,10dodecadien-1-ol, Cydia funebrana - mixture of Z8dodecene-1-yl acetate and E8-dodecene-1-yl acetate), C. molesta - a mixture of (Z)-8-dodecenyl acetate, (E)-8-dodecenyl acetate and (Z)-8-dodecen-1-ol, for Spilonota ocellana Z8-tetradecen-1-yl acetate, were supplied by Propher Březová near Zlín.

The morphology of male genitalia was studied to determine the caught moth species (RAZOWSKI, 2001; NOWACKI, 1998; SLAMKA, 1997). The study of male genitalia morphology was necessary especially for identification of $C$. funebrana and $C$. molesta. The names of moths follow LAŠTU゚VKA (1998).

\section{Characteristics of the localities under study}

Prakšice is locality, which belongs to the Carpathian area, bioregion Zlín. Characteristic of this area is the thermophilic vegetation high in the mountains and the descent of mountain species into lower locations, which results in great species diversity. Dominant are flysch deposits. The climate is continental, with local differences dependent on the altitude and on the windward or leeward face of the slopes. The vegetation zones of the area are oak, beech-oak, oakbeech and beech stands. The locality is situated in the Nature Park Prakšická vrchovina (beech vegetation zone) and is slope exposed to the south, altitude 250 $\mathrm{m}$. A beech forest (Fagetum) borders the southwest and north where oak (Quercus sp.), field maple (Acer campestre L.), common privet (Ligustrum vulgare L.) and dog rose (Rosa canina L.) are dominant species in the ecotone. It is an extensive plantation of fruit trees without chemical protection: apple-trees, peartrees, cherry-trees, plum-trees and some service trees (Sorbus domestica L.) (apparently autochthonous), the undergrowth is mainly grass with admixture of herbs e.g. Astragalus sp., Coronilla varia L., Inula ensifolia L., Rosa gallica L.

Tuřany: biogeographically this is part of the North Pannonian area with upland topography and highlands character around Pálava. The biota is thermophilic; the area lies in the oak vegetation zone with Quercus pubescens, beech-oak vegetation zone with natural representation of hornbeam (Carpinus betulus L.) and scarce beech (Fagus sylvatica L.) on the border. Pheromone traps were placed in intensive orchards of the firm Novotný where chemical protection was carried out. It is a totally open and unprotected peneplain at altitude of $227 \mathrm{~m}$, sum of precipitation $509 \mathrm{~mm}$ and average annual temperature $8.4^{\circ} \mathrm{C}$, with single bushes of rose (Rosa canina L.) and Prunus sp. The adjacent fields were used for the production of fodder plants (alfalfa). Apple-tree and peach-tree plantations were investigated. The grass undergrowth of the orchard consist of Lolium perenne L., Dactylis glomerata L. and Taraxacum officinale Zinn.

Nebovidy: the bioregion is an interface of the thermofyticum and mezophyticum.

Geologicaly this region is an armour massif with hornblende schist greenstone, with greenstone and old metabazits. The climate is relatively warm and dry, since the region lies in the moderate precipitation shadow of the Bohemian-Moravian Uplands (Českomoravská vrchovina). The soils are orthic luvisols till luvisol chernozem on loess, with cambisol and albic luvisol on the slope and bottom spine. The primary vegetative cover was Querceto-carpinetum, less Carpathian and sporadically thermophilous oak woodlans. In higher altitudes mostly beech forests prevail, on southern slopes thermophilous oak woodlans on acid field. In general the biota of this region is well preserved, with a dense net of protected areas.

The studied locality is situated near the protected landscape area Bobravská vrchovina. Part of the 
locality is an old orchard with apple-tree, cherrytree and plum-tree with admixtures of rose (Rosa canina), hawthorn (Crataegus), blackthorn (Prunus spinosa) and strawberry (Fragaria sp.), and part is a garden colony with a broad spectrum of plants of the Rosaceae family. The locality is bordered by an oak (Quercus sp.) forest abundant in Robinia pseudoacacia, and elder (Sambucus nigra) and Rubus sp. in the sub-canopy.

II: Basic characteristic of the studied localities

\begin{tabular}{|l|l|l|l|}
\hline \multicolumn{1}{|c|}{ Tuřany } & \multicolumn{1}{c|}{ Nebovidy } & \multicolumn{1}{c|}{ Prakšice } \\
\hline altitude * & 227 & 303 & 235 \\
\hline fauna square * & 6865,6866 & 6865 & 6971 \\
\hline sub-area ** & Northpanonian & Hercynian & West Carpathian \\
\hline bioregion ** & Lechovice & Brno & Zlín \\
\hline geologie ** & $\begin{array}{l}\text { gravel-sand loess- } \\
\text { covered terraces }\end{array}$ & $\begin{array}{l}\text { amfibolie granodiorites, } \\
\text { diorites and oldmetabazits }\end{array}$ & flysch with sandstone ridge \\
\hline
\end{tabular}

* Pruner \& Míka (1996)

** Culek et al (1995)

III: Physical-geographical characteristic of the localities under study according to Demek et al. (1975)

\begin{tabular}{|l|l|l|l|}
\hline Studied locality & \multicolumn{1}{|c|}{ Geomorfological regions } & \multicolumn{1}{c|}{ Climatic regions } & \multicolumn{1}{c|}{ Vegetation tier } \\
\hline $\begin{array}{l}\text { Tuřany } \\
\text { Brno- město) }\end{array}$ & $\begin{array}{l}\text { of flat hilly lands of Outer } \\
\text { Carpathian and Inner Carpathian } \\
\text { depressions and the Central Polish } \\
\text { Lowlands with accumulation surface }\end{array}$ & $\begin{array}{l}\text { warm, very dry, with a } \\
\text { moderately warm winter }\end{array}$ & oak \\
\hline $\begin{array}{l}\text { Nebovidy } \\
\text { (Brno-venkov) }\end{array}$ & $\begin{array}{l}\text { flat broken hilly lands of the } \\
\text { Bohemian Highlands with erosion- } \\
\text { denudation surface }\end{array}$ & $\begin{array}{l}\text { warm, dry, with a } \\
\text { moderately warm winter }\end{array}$ & beech-oak \\
\hline $\begin{array}{l}\text { Prakšice } \\
\text { (Uherské Hradiště) }\end{array}$ & $\begin{array}{l}\text { flat broken hilly lands of the Outer } \\
\text { Western Carpathians with erosion- } \\
\text { accumulation surface }\end{array}$ & $\begin{array}{l}\text { warm, dry, with a } \\
\text { moderately warm winter }\end{array}$ & beech-oak \\
\hline
\end{tabular}

IV: Climatic conditions characteristic of the studied localities according to Quitt (1971)

\begin{tabular}{|c|c|c|c|}
\hline Studied locality & Nebovidy & Prakšice & Tuřany \\
\hline Climatic region & $\mathbf{T 2}$ & $\mathbf{T 2}$ & T4 \\
\hline Number of summer days & \multicolumn{2}{|c|}{$50-60$} & $60-70$ \\
\hline Number of days with average temperature of $10^{\circ}$ and more & \multicolumn{2}{|c|}{$160-170$} & $170-180$ \\
\hline Number of frosty days & \multicolumn{2}{|c|}{$100-110$} & $100-110$ \\
\hline Number of icy days & \multicolumn{2}{|c|}{$30-40$} & $30-40$ \\
\hline Average air temperature in January & \multicolumn{2}{|c|}{$-2--3$} & $-2--3$ \\
\hline Average air temperature in April & \multicolumn{2}{|c|}{$8-9$} & $9-10$ \\
\hline Average air temperature in July & \multicolumn{2}{|c|}{$18-19$} & $19-20$ \\
\hline Average air temperature in October & \multicolumn{2}{|c|}{$7-9$} & $9-10$ \\
\hline Average number of days with precipitation of $1 \mathrm{~mm}$ and more & \multicolumn{2}{|c|}{$80-100$} & $80-90$ \\
\hline Sum of precipitation in vegetation period & \multicolumn{2}{|c|}{$350-400$} & $300-350$ \\
\hline Sum of precipitation in winter period & \multicolumn{2}{|c|}{$200-300$} & $200-300$ \\
\hline Number of days with snow cower & \multicolumn{2}{|c|}{$40-50$} & $40-50$ \\
\hline Number of cloudy days & \multicolumn{2}{|c|}{$120-140$} & $110-120$ \\
\hline Number of bright days & \multicolumn{2}{|c|}{$40-50$} & $50-60$ \\
\hline
\end{tabular}


$\mathrm{V}$ : Exploatation of adjacent land

\begin{tabular}{|l|l|l|l|}
\hline Exploatation of adjacent land & Tuřany & Nebovidy & Prakšice \\
\hline 2000 & alfalfa & gardens & forest, gardens \\
\hline 2001 & alfalfa & gardens & forest, gardens \\
\hline 2002 & alfalfa, sunflower & gardens & forest, gardens \\
\hline 2003 & alfalfa & gardens & forest, gardens \\
\hline
\end{tabular}

\section{RESULTS}

In the course of monitoring tortricid moth species Adoxophyes orana, Archips podanus, A. rosanus, Hedya nubiferana, Spilonota ocellana, Pandemis heparana and Cydia molesta, Cydia pomonella and Cydia funebrana as references species, also other moth species were captured in the pheromone traps; in 2002 moths from the family Tortricidae Pammene albuginana, Cydia coronillana, Notocelia rosaecolana, Spilonota ocellana, Adoxophyes orana, Pandemis cerasana, Archips rosanus and Hedya pruniana, from the family Pyralidae Pyrausta rectefascialis and $P$. aurata, from the family Noctuidae Noctua pronuba and from the family Yponomeutidae Yponomeuta malinellus (Zeller, 1838).

In 2003 the other species captured in the pheromone traps were moths of the family Tortricidae Epiblema scutulanum (Den. \& Schiff. 1775); C. funebrana, Celypha striana (Den. \& Schiff. 1775), C. molesta, C. pomonella, Pammene suspectana (Lng. \& Zeller, 1846), C. coronillana (Lng. \& Zeller, 1846), Enarmonia formosana (Scopoli, 1763), Notocelia roborana (Den. \& Schiff. 1775), N. rosaecolana (Doubleday, 1850), Epinotia huebneriana Koçak, 1980, from family Noctuidae Noctua pronuba, Agrotis segetum (Den. \& Schiff. 1775), Euxoa tritici
(Linnaeus, 1761), Amphipoea oculaea (Linnaeus, 1761), from family Lymantriidae Lymantria dispar (Linnaeus, 1758) and from Zygaenidae Zygaena purpuralis (Brünnich, 1763).

The occurrence of non-target species was either regular (R) (specimens of non-target species were captured in the pheromone traps in large numbers, or in a 14-day interval) or sporadic (S) (the individual specimens of non-target species were captured in the pheromone traps). Reciprocal attractiveness of the pheromones for the species C. funebrana and $C$. molesta was observed in both localities. Catching $C$. coronillana to the pheromone traps for C. funebrana is not possible, due to the large number of caught individuals and the length of the period when these species were present in traps; it is considered as accidental. The situation was similar for pheromones of Pandemis heparana, whose pheromone attracted Noctua pronuba. The pheromones of C. funebrana and $C$. molesta attracted Notocelia rosaecolana, probably there is a common pheromone compound, this theory is supported by the reciprocal attractiveness of pheromones of $C$. funebrana and $C$. molesta. An admixture in the pheromones for target species might be the reason for the attractiveness of these pheromones for $N$. rosaecolana.

VI: The presence of non-target lepidoptera species in pheromone traps for tortricid moths in the Prakšice and Tur̆any localities in 2002

\begin{tabular}{|l|l|l|c|}
\hline \multicolumn{1}{|c|}{ Locality } & \multicolumn{1}{|c|}{ Target species } & \multicolumn{1}{c|}{ Non-target species } & $\begin{array}{c}\text { Regularity of occurrence/ } \\
\text { number of individuals }\end{array}$ \\
\hline $\begin{array}{l}\text { Brno- } \\
\text { Tuřany }\end{array}$ & Pandemis heparana & Noctua pronuba & $\mathrm{R} / 28$ \\
\cline { 2 - 4 } & Cydia funebrana & Notocelia rosaecolana & $\mathrm{R} / 8$ \\
\cline { 2 - 4 } & C. molesta & Notocelia rosaecolana & $\mathrm{S} / 3$ \\
& & Spilonota ocellana & $\mathrm{S} / 3$ \\
& & Adoxophyes orana & $\mathrm{S} / 2$ \\
& & Archips rosanus & $\mathrm{S} / 1$ \\
& & Pandemis cerasana & $\mathrm{S} / 2$ \\
\cline { 3 - 4 } & C. pomonella & Hedya nubiferana & $\mathrm{S} / 1$ \\
\cline { 2 - 4 } & Spilonota ocellana & Hedya pruniana & $\mathrm{S} / 2$ \\
\cline { 2 - 4 } & Hedya nubiferana & Pammene albuginana & $\mathrm{S} / 1$ \\
\hline
\end{tabular}




\begin{tabular}{|l|l|l|c|}
\hline Prakšice & C. pomonella & Pammene albuginana & $\mathrm{S} / 2$ \\
\cline { 2 - 4 } & Cydia funebrana & Cydia coronilana & $\mathrm{R} / 13$ \\
\cline { 2 - 4 } & P. cerasana & $\begin{array}{l}\text { Yponomeuta malinella } \\
\text { (Yponomeutdae) } \\
\text { Pyrausta rectefascialis } \\
\text { (Pyralidae) } \\
\text { Pyrausta aurata (Pyralidae) }\end{array}$ & $\mathrm{S} / 4$ \\
& & $\mathrm{~S} / 3$ \\
\hline
\end{tabular}

VII: The presence of nontarget lepidoptera species in the pheromone traps for tortricide moths in localities of Prakšice and Tur̆any in 2003

\begin{tabular}{|c|c|c|c|}
\hline Locality & Target species & Non-target species & $\begin{array}{l}\text { Regularity of occurrence/ } \\
\text { number of individuals }\end{array}$ \\
\hline \multirow[t]{8}{*}{ Tuřany } & C.molesta & Epiblema scutulanum & $\mathrm{R} / 15$ \\
\hline & & C. funebrana & $\mathrm{R} / 71$ \\
\hline & C. funebrana & C. molesta & $\mathrm{R} / 56$ \\
\hline & & Celypha striana & $\mathrm{R} / 9$ \\
\hline & & E. scutulanum & $\mathrm{R} / 20$ \\
\hline & & Agrotis segetum & $\mathrm{S} / 1$ \\
\hline & & Pammene suspectana & $\mathrm{S} / 1$ \\
\hline & Pandemis heparana & Noctua pronuba & $\mathrm{R} / 9$ \\
\hline \multirow[t]{6}{*}{ Nebovidy } & C. funebrana & C. molesta & $\mathrm{R} / 15$ \\
\hline & & C. coronillana & $\mathrm{R} / 7$ \\
\hline & C. molesta & C. funebrana & $\mathrm{R} / 27$ \\
\hline & & Enarmonia formosana & $\mathrm{S} / 3$ \\
\hline & Adoxophyes orana & Lymantria dispar & $\mathrm{S} / 3$ \\
\hline & Hedya nubiferana & Hedya pruniana & $\mathrm{R} / 5$ \\
\hline \multirow[t]{17}{*}{ Prakšice } & Adoxophyes orana & Lymantria dispar & $\mathrm{S} / 2$ \\
\hline & C.molesta & Enarmonia formosana & $\mathrm{S} / 4$ \\
\hline & & Notocelia roborana & $\mathrm{S} / 1$ \\
\hline & & Notocelia rosaecolana & $\mathrm{S} / 1$ \\
\hline & & C. funebrana & $\mathrm{R} / 61$ \\
\hline & C. funebrana & N. roborana & $\mathrm{S} / 3$ \\
\hline & & C. coronillana & $\mathrm{R} / 11$ \\
\hline & & C. molesta & $\mathrm{R} / 48$ \\
\hline & & S. ocellana & $\mathrm{S} / 1$ \\
\hline & C. pomonella & N. roborana & $\mathrm{S} / 1$ \\
\hline & & Amphipoaea oculaea & $\mathrm{S} / 1$ \\
\hline & H. nubiferana & C. pomonella & $\mathrm{S} / 1$ \\
\hline & & Eucosma fervidana & $\mathrm{S} / 1$ \\
\hline & & C. funebrana & $\mathrm{S} / 1$ \\
\hline & A. orana & Zygaena purpuralis & $\mathrm{S} / 1$ \\
\hline & S. ocellana & Epinotia huebneriana & $\mathrm{S} / 1$ \\
\hline & & Euxoa tritici & $\mathrm{S} / 1$ \\
\hline
\end{tabular}




\section{DISCUSSION}

The reciprocal attractiveness of the pheromone for C. funebrana and C. molesta is known. HRDÝ et al. (1997) reported the presence of the species Pammene amygdalana, $P$. aurita and $P$. suspectana in pheromone traps for $C$. funebrana. In these pheromone traps HRDÝ et al. (1993) discovered Celypha striana (Den. \& Schiff., 1775), a species attracted by the pheromone for C. funebrana in Turrany in 2003. The pheromone of $C$. striana consist of Z 8-12 OH (www.nysaes.cornell.edu). The species of the tribe Archipini have a common component of pheromone (Z)-11-tetradecenyl acetate (OKU, 1993). Pammene spiniana was also caught into pheromone traps for $C$. molesta a $C$. funebrana (MAYER \& MCLAUGHLIN in HRDÝ et al. 1997) while the pheromone for $C$. funebrana was an attractant for the species Pammene aurana (HRDÝ et al. 1997). HRDÝ et al. (1989) detected the presence of Hedya pruniana in pheromone traps for $C$. molesta. In Turany Hedya pruniana was attracted by the $S$. ocellana pheromone, where the nutritive plants for this tortricid species (family Rosaceae) grow on the edge of the plantation. The species C. molesta and $S$. ocellana have common components of the pheromone (Z)-8-dodecenyl acetate and (E)-8-dodecenyl acetate (MC BRIEN et al. 1992). (Z)-8-dodecenyl acetate is the component of the sex pheromone of Hedya (FRÉROT et al. 1979). The pheromone of $P$. heparana attracts Noctua fimbriata (Noctuidae) (HRDÝ et al. 1989). In Tuřany the species Noctua pronuba was caught in the traps for $P$. heparana, a commonly spread species living on a wide spectrum of nutritive plants. HRDÝ et al. (1979) reported the presence of Epiblema scutulana in pheromone traps for $C$. funebrana and $C$. molesta. When monitoring of $C$. pomonella in Japan HIRAMATSU et al. (1992) dicovered that the pheromone of this species was an attractant for males of the genera Aterpia, Hedya, Eucosma, Grapholita and Pammene. These data correspond with findings of Pammene albugina$n a$ in pheromone traps of $C$. pomonella in Prakšice. The pheromone for Hedya nubiferana and C. molesta attracted Cydia janthiana (HRDÝ et al., 1997). The pheromone of Hedya nubiferana was an attractant for Pammene albuginana in Tuřany, where oaks grow in the nearest wind-break. This effect could be caused by (Z)-8-dodecenyl acetate, a common component of sex pheromones of both these species (FRÉROT et al. 1979). The reciprocal presence of $C$. funebrana and C. molesta in pheromone traps for both of these species was recorded in both localities. The average representation of $C$. funebrana in pheromone traps for this species was $79.4 \%$, the representation of $C$. molesta in pheromone traps for C. molesta was $62.5 \%$ in year 2002, and $78.1 \%$ and $67.7 \%$ in 2003 respectivelly. RAULEDER (2002) reported an average of $97.4 \%$ males of these species in the traps for C. funebrana. In the extensive orchard in Prakšice 7 non-target lepidopteran species were captured in the pheromone traps for target species of the family Tortricidae, out of which Cydia coronillana, Pammene albuginana, Pyrausta rectefascialis and $P$. aurata are not pests of fruit trees of the family Rosaceae and their presence is dependent on ecological conditions, especially on the presence of host plants. In Turany, 12 non-target species were caught, out of which only Noctua pronuba, Notocelia rosaecolana, Hedya pruniana and Pammene albuginana are not pests of fruit trees.

\section{The characteristics of non-target species}

Celypha striana (Den. \& Schiff., 1775) is widely spread in Central Europe. The caterpillars lives on Taraxacum officinale (Asteraceae) and Plantago lanceolata (Plantaginaceae) from September to May, the moths fly from June to August (RAZOWSKI, 2001). The pheromone of this species consist of (Z)8- dodecen-1-ol (www.nysaes.cornel.edu) .

Cydia coronillana (Lienig \& Zeller, 1846) (Grapholitini): caterpillars appear from June to September, moths fly from the late April to July. It is a relatively abundant species on meadows, on forest edges and other localities where Coronilla varia (Fabaceae) occurs (RAZOWSKI, 2001).

Enarmonia formosana (Scopoli, 1763) is pest of stems of Prunus avium, P. domestica, P. armeniaca, $P$. persica, Cerasus, Pyrus communis, Malus sylvestris, Sorbus and other species of the Rosaceae family. The caterpillars feed on nutritive plants from September to May and from mid- May (June) to July (August). (RAZOWSKI, 2001)

Epiblema scutulanum (Den. \& Schiff., 1775) occurs in open habitats. The catterpillars feed from June to April on Carduus nutans, Cirsium vulgare, Arctium and Centaurea. The moths fly from midApril to August (RAZOWSKI, 2001).

Epinotia huebneriana Koçak, 1980 is local and not abundant species. Caterpillars feed on Rubus e.g. $R$. fruticosus) from May to June and moths fly from June to July. (RAZOWSKI, 2001).

Eucosma fervidana (Zeller, 1847) is not abundant species. The caterpillars feed on Aster amellus and Solidago virgauraea (Asteraceae) from April to May, the moths fly from June to August (RAZOWSKI, 2001).

Hedya pruniana (Hübner, 1799); the caterpillars feed from June (August) to April (May), the moths fly from May to August. The nutritive plants are Prunus spinosa, Crataegus, Rosa, Sorbus and Corylus avellana (Corylaceae). This species is widely spread in Central Europe (RAZOWSKI, 2001).

Pammene albuginana (Guenée, 1845) (Eucosmini): The caterpillars feed from September and Octo- 
ber to March on oak (Quercus: Fagaceae) in galls of Hymenopteran insects (Hymenoptera). This moth occurs locally in oak forests of Central Europe (RAZOWSKI, 2001).

Pammene suspectana (Lng. \& Zeller, 1846) is rarely occurring species feeding on Fraxinus excelsior. The moth fly mid-April to June (RAZOWSKI, 2001).

Notocelia rosaecolana (Doubleday, 1850) (Tortricidae, Eucosmini): caterpillars appear from May to June, the moths fly from late May to July, sometimes untill August. The nutritive plant is rose (Rosa: Rosaceae). This species is relatively abundant on the edges of parks, forests, in shrubby biotopes and in gardens (RAZOWSKI, 2001).

Notocelia roborana (Hübner, 1796) is spread in Central Europe. Catterpillars appear on Rosa sp., Rubus, Prunus spinosa, Crataegus and Quercus untill June. The moths fly from June to mid-August. (RAZOWSKI, 2001).

Noctua pronuba (Linnaeus, 1758) (Noctuidae) is a euryoecous species spread in open habitats, including anthropogenic-affected ones. The caterpillars feed on different herb species. The moths fly from June to September (NOWACKI, 1998).

Euxoa tritici (Linnaeus, 1761) occurs in areas from lowlands to middle altitudes, on the edges of forest and fields; catterpillars feed on Poaceae from September to May, the moths fly from June to September (NOWACKI, 1998).

Agrotis segetum (Den. \& Schiff., 1775) is an euryecous species spread in forest edges, shrubby biotopes, lowlands, fields and gardens. Caterpillar feed on grass (Poaceae) from September to April and from July to August, the moths fly from May to June and from August to October (NOWACKI, 1998).

Amphipoea oculaea (Linnaeus, 1761) a species abundant from lowland to mountain localities, catterpillars feed on grass (Poaceae) from May to July and the moths fly from June to September (NOWACKI, 1998).

Yponomeuta malinellus (Zeller, 1838) (Yponomeutidae) moths fly from June to August. Caterpillars spin nests from leaves of apple-trees. They may cause clear-eatings during mass outbreaks (HLUCHÝ et al. 1997).

Pyrausta rectefascialis Toll, 1936 (Pyralidae) is a species spread in Central Europe in Moravia,
Slovakia, in Poland, Austria, Hungary, Romania and Bavaria. It occurs in dry and warm habitats and on open land. Caterpillars supposedly live on plants of the family Lamiaceae (SLAMKA, 1997).

Pyrausta aurata (Scopoli, 1763) (Pyralidae) is a moth spread in dry habitats on open agricultural land. It has two generations per year and the moths fly from April to September. Caterpillars live between spinned leaves from June to May of the following year on plants of the genus Thymus, Origanum, Mentha and Salvia (SLAMKA, 1997).

Zygaena purpuralis (Brünnich, 1763) is common widely spread euryecous species. Caterpillars feed on the thyme (Thymus serpyllum) from August to May, the moths fly from June to August (KOCH, 1984).

Lymantria dispar (Linnaeus, 1758) is abundant from lowlands to warmer mountain localities in deciduous forest, gardens, orchards, alleys and parks. Caterpillars are calamity pests in oak forests. They feed on Quercus sp., Carpinus betulus and Salix spp. and appear from April to June; the moths fly from June to September (KOCH, 1984).

\section{CONCLUSION}

The presence of non-target tortricid moths in the pheromone traps, which are habitually similar to the pest, is of particular importance because it may distort the data used for treatment prediction. During the monitoring of the tortricid bud moths, the species Pammene albuginana, Cydia coronillana and Notocelia rosaecolana from the family Tortricidae were found in pheromone traps for target tortricid species. The presence of non-target species in the pheromone traps (e.g. Noctua pronuba) may even cancel out the sticky board. Pyrausta rectefascialis and $P$. aurata have no practical value. Therefore it is important to know what pheromone is able to attract non-target species and what is the cause of this effect. One reasons may be the presence of common components in pheromones prepared for the individual investigated species. These components may be natural ingredients of the pheromone or impurities from the production process. Another reason for the presence of non-target species in pheromone traps may be the false response of males of non-target species to synthetic pheromones for the studied species.

\section{SOUHRN}

Necílové druhy motýlů prrítomné ve feromonových lapačích pro vybrané druhy obalečů v letech 2002 a 2003

Přítomnost necílových druhů motýlů ve feromonových lapačích, zvláště těch, které jsou habituálně podobné sledovaným druhům škůdců, může zkreslit data získávaná pro signalizaci ošetření. Při 
monitorování pupenových obalečů byly ve feromonových lapačích přítomny další druhy z čeledi Tortricidae: Pammene albuginana, Cydia coronillana a Notocelia rosaecolana. Necílové druhy mohou také zničit lepové desky (např. Noctua pronuba). Pyrausta rectefascialis a $P$. aurata praktický význam nemají. Důležité je zjištění, který feromon může být atraktantem pro necílové druhy. Důvodem atraktivity feromonu může být přítomnost složky společné pro více druhů motýlů, př́itomnost nečistoty vzniklá při výrobě, nebo špatná odpověd’ samců necílových druhů na podnět syntetického feromonu.

pupenoví obaleči, feromonové lapače, Jižní Morava, intenzivní sady, extenzivní sady, neúčelové druhy, Noctuidae, Pyralidae, Yponomeutidae

Supported by the Ministry of Education, Youth and Sports of the Czech Republic. Grant No: CEZ:J08/ 98:43210001

\section{REFERENCES}

CULEK, M. (editor): Biogeografické členění České republiky. Enigma Praha pro MŽP ČR. 1995, $347 \mathrm{p}$.

DEMEK, J., QUITT, E., RAUŠER, J., BALATKA, B., CZUDEK, T., KOUSAL, J., LOUČKOVÁ, J., SLÁDEK, J.: Fyzickogeografické regiony ČSR (Physico-geographical regions of the Czech socialist republic. Geografický ústav ČSAV Brno. Czechoslovak Academy of Sciences, Institute of Geography, Brno, 1975.

FRÉROT B., PRIESNER E., GALLOIS M.: A sex attractant for the green budworm moth (Hedya nubiferana). Z. Naturfors., 1979, 34 (12): 1248-1252.

HIRAMATSU, I., OHKUBO, K., KADOI, M.: Tortricid moths caught by sex pheromone traps for codling moth. Res. Bull. Plant Protect. Service. Jpn, 1992, 28: 33-39.

HLUCHÝ, M., ACKERMANN, P., ZACHARDA, M., BAGAR, M., JETMAROVÁ, E., VANEK, G.: Obrazový atlas chorob a škůdců ovocných dřevin a révy vinné. Ochrana ovocných dřevin a révy vinné $\mathrm{v}$ integrované produkci. Biocont Laboratory s. r. o., Brno, 1997.

HRDÝ, I., MAREK, J., KRAMPL, F.: Sexual pheromone activity of 8-dodecenyl and 11-tetradecenyl acetates for males of several lepidopteran species in field trials. Acta Entomol. Bohemoslov., 1979, 76: 65-84.

HRDÝ, I., VRKOČ, J., HOCHMUT, R.: New records on sex atractants for males and faunistic comments on moths (Lepidoptera) from Czechoslovakia. Acta Entomol. Bohemoslov., 1989, 86: 252-268.

HRDÝ I., MAREK J., KRAMPL F., KULDOVÁ J., BARABÁS L.: Distribution of the fruit tree pests Cydia molesta, Cydia funebrana and Anarsia lineatella (Lepidoptera: Tortricidae, Gelechidae) in former Czechoslovakia as recorded by pheromone traps. Acta Soc. Zool. Bohem., 1993, 58: 53-60.

HRDÝ, I., KRAMPL, F., KULDOVÁ, J., KALINOVÁ, B.: Výskyt potenciálních škůdců sadů, oba- leče slivoňového, Cydia lobarzewskii a obaleče trnkového, C. janthiana (Lepidoptera: Tortricidae) v České republice a poznámky $\mathrm{k}$ dalším druhům podle úlovků do feromonových lapáků. Klapalekiana, 1997, 33: 155-172.

KOCH, M.: Wir bestimmen Schmetterlinge. Neumann Verlag Lepzig. 1984, 792 p.

LAŠTU゚VKA, Z. (ed.): Seznam motýlů české a Slovenské republiky. Brno: Konvoj, 1998.

LOFSTEDT, C., LANNE, B. S., LOFQVIST, J., APPELGREN, M., BERGSTROM, G.: Individual variation in the pheromone of the turnip moth, Agrotis segetum Schiff. Lepidoptera, Noctuidae. Journal of Chemical Ecology. 1985, 11 (9): 1181-1196

MCBRIEN, H., GRIES, G., GRIES, R., BORDEN, J. H., JUDD, G. J. R., KING, G. G. S., SLESSOR, K. N.: Sex pheromone components of the eyespoted bud moth, Spilonota ocellana (Denis and Schiffermüller) (Lepidoptera: Olethreutinae). Can. Ent., 1992, 124: 1391-1394.

NOWACKI, J.: The Noctuids (Lepidoptera, Noctuidae) of Central Europe. F. Slamka Bratislava, 1998.

OKU, T.: Suppression of lepidopterous pest populations in apple orchards through mating disruption with synthetic sex-pheromones. JARQ - Jpn Agr. Res. Q., 1993, 26: 271-76.

PRUNER, L., MÍKA, P.: Seznam obcí a jejich částí v České republice s čísly mapových polí pro sít'ové mapování fauny. (List of settlements in the Czech republic with associated map fields codes for faunistic grid mapping system.) Klapalekiana, 1996, suppl. vol. 32

QUITT, E.: Klimatické oblasti Československa. Studia Geographica 16. Geografický ústav ČSAV, Brno, 1971.

RAULEDER, H.: Beobachtungen zur Lebensweise des Pflaumenwicklers (Cydia funebrana). Gesunde Pflanzen, 2002, 54: 241-248.

RAZOWSKI, J.: Die Tortriciden (Lepidoptera, Tortricidae) Miteleuropas. F. Slamka Bratislava, 2001.

ROELOFS, W. L., BROWN, R. L.: Pheromones and 
evolutionary relationships of Tortricidae. Annual Review of Ecology and Systematics. 1982, 13: 395-422 (g)

SLAMKA, F.: Die Zünslerartigen (Pyraloidea) Mitteleuropas. Bestimmen-Verbreitung-Flugstandort-Lebensweise der Raupen. F. Slamka Bratislava, 1997.

SVENSSON, M. G. E., BENGTSSON, M., LO-
FQVIST, J.: Individual variation and repeatability of sex pheromone emission of female turnip moths Agrotis segetum. Journal of Chemical Ecology., 1997, 23: 7, 1833-1850.

http://www.nysaes.cornell.edu/fst/faculty/acree/ pheronet/phlist/celypha.html (4. 2. 2004)

Ing. Eva Hrudová, Ph.D. Ústav pěstování, šlechtění rostlin a rostlinolékařství, Mendelova zemědělská a lesnická univerzita v Brně, Zemědělská 1, 61300 Brno, Česká republika, e-mail: hrudova@mendelu.cz 